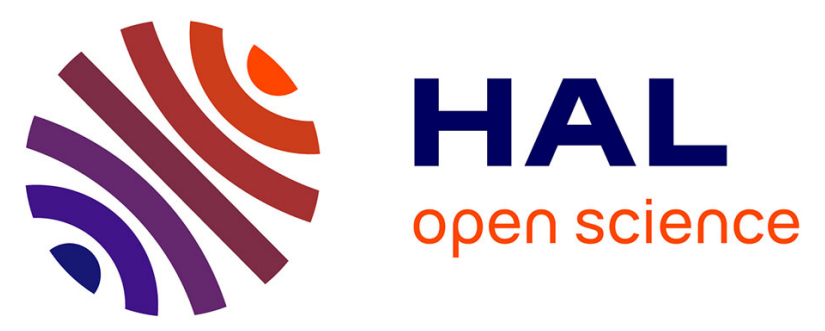

\title{
Correlation between thermostability and stability of glycosidases in ionic liquid
}

Salim Ferdjani, Marina Ionita, Bimalendu Roy, Michel Dion, Zeineddine

Djeghaba, Claude Rabiller, Charles Tellier

\section{- To cite this version:}

Salim Ferdjani, Marina Ionita, Bimalendu Roy, Michel Dion, Zeineddine Djeghaba, et al.. Correlation between thermostability and stability of glycosidases in ionic liquid. Biotechnology Letters, 2011, pp.1215-1219. 10.1007/s10529-011-0560-5 . hal-00671649

\section{HAL Id: hal-00671649 \\ https://hal.science/hal-00671649}

Submitted on 18 Feb 2012

HAL is a multi-disciplinary open access archive for the deposit and dissemination of scientific research documents, whether they are published or not. The documents may come from teaching and research institutions in France or abroad, or from public or private research centers.
L'archive ouverte pluridisciplinaire HAL, est destinée au dépôt et à la diffusion de documents scientifiques de niveau recherche, publiés ou non, émanant des établissements d'enseignement et de recherche français ou étrangers, des laboratoires publics ou privés. 


\title{
Correlation between thermostability and stability of glycosidases in ionic liquid
}

\author{
Salim Ferdjani ${ }^{\mathrm{a}, \mathrm{b}}$, Marina Ionita ${ }^{\mathrm{a}}$, Bimalendu Roy ${ }^{\mathrm{a}}$, Michel Dion ${ }^{\mathrm{a}}$, Zeineddine \\ Djeghaba $^{\mathrm{b}}$, Claude Rabiller ${ }^{\mathrm{a}}$ and Charles Tellier ${ }^{\mathrm{a}^{*}}$ \\ ${ }^{a}$ Biotechnologie, Biocatalyse et Biorégulation, UMR 6204 CNRS, Université de \\ Nantes, 2, rue de la Houssinière, F-44322 Nantes cedex 03, France \\ ${ }^{b}$ Laboratoire de Chimie Organique Appliquée, Université Badji Mokhtar, BP 12 \\ Annaba-Algeria \\ Corresponding author: $\mathrm{C}$. Tellier \\ Tel: +33251 125733 \\ Fax: +33251 125722 \\ E-mail: charles.tellier@univ-nantes.fr \\ URL : http://umr6204.univ-nantes.fr/
}

\begin{abstract}
The activity and stability of a $\beta$-glycosidase (Thermus thermophilus) and two $\alpha$ galactosidases (Thermotoga maritima and Bacillus stearothermophilus) were studied in different hydrophilic ionic liquid (IL)/water ratios. For the ILs used, the glycosidases showed the best stability and activity in 1,3-dimethylimidazolium methyl sulfate [MMIM] [MeSO$\left.{ }_{4}\right]$ and 1,2,3trimethylimidazolium methyl sulfate [TMIM] $\left[\mathrm{MeSO}_{4}\right]$. A close correlation was observed between the thermostability of the enzymes and their stability in IL media. At high IL concentration (80\%), a time-dependent irreversible denaturing effect was observed on glycosidases while, at lower concentration ( $<30 \%)$, a reversible inactivation affecting mainly the $k_{\text {cat }}$ was obtained. The results demonstrate that highly thermostable glycosidases are more suitable for biocatalytic reactions in water-miscible ILs.
\end{abstract}

Keywords: Glycosidases, ionic liquid, Thermotoga maritima, Thermus thermophilus 


\section{Introduction}

Due to the well-recognized biological role of oligosaccharides, there is still a great need for green and low cost methods for their preparation despite the considerable development of efficient synthetic methods (Muthana et al. 2009). In the last decade, enzyme-catalyzed reactions have proved to be very efficient for building the glycosidic bond due to their stereoselectivity (Hanson et al. 2004). For this purpose, glycoside hydrolases have been particularly investigated but their use is limited by the competition between hydrolysis and transglycosylation reactions which are both catalyzed by these enzymes. To overcome this limitation, several protein engineering strategies, based on site directed mutagenesis (Mackensie et al. 1998) or molecular directed evolution (Feng et al. 2005), have been proposed to reduce and even eliminate the hydrolytic activities of glycosidases while keeping the transglycosylation activities. Other alternatives suggested to prevent the undesirable hydrolysis reaction were reducing the water activity by using organic solvents (van Rantwijk et al. 1999) or using frozen buffer (ChiffoleauGiraud et al. 1997). However, most of the water-immiscible solvents do not dissolve carbohydrate substrates while water-miscible solvents, such as DMSO and DMF, although dissolving carbohydrates, generally inactivate glycosidases at concentrations above $20 \%$.

Recently, ionic liquids (ILs) have received attention as a promising new class of solvent for chemo- and bio-catalytic organic synthesis (Sheldon et al. 2002). Due to their ability to dissolve polar substrates such as amino-acids or carbohydrates in a low-water environment, several enzymes, mainly esterases, lipases and 
proteases, have been assayed in ILs and shown to retain biocatalytic activity even at low-water activity (Van Rantwijk and Sheldon 2007). However, a limited number of studies has been devoted to the use of ILs as solvents for reactions catalyzed by glycosidases (Kaftzik et al. 2002; Kamiya et al. 2008; Lang et al. 2006), even though ILs present interesting properties such as their capacity to solubilize both carbohydrates and enzymes.

The objective of this work was to study the stability and the activity of several glycosidases at different IL/water ratios. Three retaining glycosidases, which differ in thermostability, were chosen for this study: $\alpha$-galactosidase from Bacillus stearothermophilus (AgaB), $\alpha$-galactosidase from Thermotoga maritima (TmGalA), and $\beta$-glycosidase from Thermus thermophilus (Tt $\beta g l y)$.

\section{Materials and methods}

\section{Materials}

$p$-Nitrophenyl $\alpha$ - and $\beta$-galactoside ( $p$ NP $\alpha$ gal and $p$ NP $\beta$ gal, respectively), 1,3dimethylimidazolium methyl sulfate ([MMIM][MeSO 4$])$ and 1,2,3trimethylimidazolium methyl sulfate ([TMIM] $\left.\left[\mathrm{MeSO}_{4}\right]\right)$ were purchased from Sigma-Aldrich and used without any further purification, as NMR spectra of these compounds did not present any detectable contaminant.

\section{Glycosidase expression and purification}

The $\alpha$-galactosidase (TmGalA) gene cloned into a pET2b vector was kindly provided by Professor Robert M. Kelly from the University of North Carolina (Raleigh, USA). This vector was used to transform E. coli BL-21(DE3). Expression and purification of the TmGalA enzyme were performed as previously described (Comfort et al. 2007). Expression of the Tt $\beta$ gly gene was carried out in 
the E. coli BL-21(DE3) strain (Novagen) using the vector pET21a (Novagen). Overexpression and purification of the Tt $\beta$ gly enzyme were conducted as previously described (Feng et al. 2005). The $\alpha$-galactosidase AgaB was overexpressed in XL1 blue cells and purified according to the procedure described in a previous paper (Dion et al. 2001). Protein concentration and purity were determined using microcapillary electrophoresis (Agilent) with bovine serum albumin as standard.

\section{Enzyme kinetics and activity}

For determination of the kinetic parameters at different concentrations of IL, stock solutions of IL/buffer $(0-70 \% \mathrm{v} / \mathrm{v})$ were prepared and the $\mathrm{pH}$ was adjusted by adding $1 \mathrm{M} \mathrm{HCl}$. In order to measure the initial activity of the glycosidases using the hydrolysis of $p \mathrm{NP} \alpha \mathrm{gal}$ and $p \mathrm{NP} \beta \mathrm{gal}, \varepsilon_{405}$ was then determined at each $\mathrm{pH}$ and for each IL/ $\mathrm{H}_{2} \mathrm{O}$ ratio, since increasing the IL content in a mixed IL/ $\mathrm{H}_{2} \mathrm{O}$ solution strongly affected the extinction coefficient of $p$-nitrophenol.

Kinetic studies were performed on a microtiter plate reader (iEMS, Labsystem) at $40^{\circ} \mathrm{C}$ and $405 \mathrm{~nm}$ using $p \mathrm{NP} \alpha$ gal and $p \mathrm{NP} \beta$ gal as substrates. Kinetic experiments with the $\alpha$-galactosidase (TmGalA) were carried out in $25 \mathrm{mM}$ citrate/phosphate buffer, $50 \mathrm{mM} \mathrm{NaCl}$, pH 6.5. Kinetic studies with other glycosidases were performed in $50 \mathrm{mM}$ phosphate buffer, $\mathrm{pH}$ 7. The kinetic parameters of the glycosidase were estimated by a direct fit of the data to the Michaelis-Menten equation using the Origin 7 program (OriginLab Corp.)

\section{Stability of glycosidases in ILs}

The stability of glycosidases in the presence of IL solutions was investigated by incubating the enzymes in an $80 \%$ (v/v) IL/buffer solution (pH 6.5, $25 \mathrm{mM}$ citrate/phosphate buffer, $50 \mathrm{mM} \mathrm{NaCl}$ for TmGalA and $\mathrm{pH}$ 7, $50 \mathrm{mM}$ phosphate 
buffer for the other glycosidases.) at $40^{\circ} \mathrm{C}$ for different times. Then, the remaining enzymatic activity was determined at regular time intervals after dilution in buffer to give 5\% (v/v) IL. Residual activities were determined at $1 \mathrm{mM}$ substrate concentration from initial rates using the standard procedure described above.

\section{Results and discussion}

\section{Selection of the ionic liquid}

First, as the composition of ILs has a significant impact on enzymatic activity, the hydrolytic activities of the $\beta$-glycosidase from Thermus thermophilus were determined in different water-miscible ILs (Supplementary Table 1) and at different concentrations in buffer $(0-33 \% \mathrm{v} / \mathrm{v}$ IL) at $\mathrm{pH} 7$. In agreement with previous studies (Kragl et al. 2002), [MMIM][MeSO 4$]$ and [TMIM][MeSO 4 ILs were less deleterious to the activity of Tt $\beta g l y$, as more than $20 \%$ of its activity was retained at 33\% (v/v) IL concentration (supplementary Fig. 1). Tt $\beta g l y$ showed approximately the same activity profile in $[\mathrm{MMIM}]\left[\mathrm{MeSO}_{4}\right]$ and in $[\mathrm{TMIM}]\left[\mathrm{MeSO}_{4}\right]$, but the enzyme was more soluble in $[\mathrm{MMIM}]\left[\mathrm{MeSO}_{4}\right]$ at high IL concentration. Hence, this IL was selected for further experiments on other glycosidases.

\section{Relation between thermostability and activity of glycosidases in ILs}

The effect of ILs on a specific glycosidase has been reported (Kaftzik et al. 2002; Lang et al. 2006) but not the relationship between enzyme thermostability and its resistance to high concentrations of ILs. Hence, we studied the effect of various concentrations of $[\mathrm{MMIM}]\left[\mathrm{MeSO}_{4}\right](0-63 \% \mathrm{v} / \mathrm{v}$ IL) on the activity of glycosidases that differ in their thermostability. Figure 1 represents the residual activity of TmGalA from Thermotoga maritima, Tt $\beta g l y$ from Thermus 
thermophilus and AgaB from Bacillus stearothermophilus at increasing concentrations of $[\mathrm{MMIM}]\left[\mathrm{MeSO}_{4}\right]$. The temperature stability (time required to lose $50 \%$ of activity) of these enzymes is $70 \mathrm{~min}$ (Miller et al. 2001), $10 \mathrm{~min}$ (Dion et al. 1999) and $2 \mathrm{~min}$ at $90^{\circ} \mathrm{C}$, respectively. The different behavior of these three enzymes in IL media appears to be closely correlated to their thermostability. TmGalA, which is the most thermostable enzyme, clearly exhibits a greater activity at high IL concentration.

\section{Relation between thermostability and stability of glycosidases in ILs}

We also addressed the reversibility of the inactivation at high IL concentration by measuring the residual activity of these enzymes after their incubation at high IL concentration $\left(80 \%[\mathrm{MMIM}]\left[\mathrm{MeSO}_{4}\right]\right)$ with increasing time. After the solution was diluted in order to reach $5 \%(\mathrm{v} / \mathrm{v})$ IL, the residual enzymatic activity was determined using $p$ NP $\alpha$ gal as a substrate (Figure 2). Full reversibility of the inactivation was obtained for TmGalA even after 2 hours of incubation in $80 \%$ $[\mathrm{MMIM}]\left[\mathrm{MeSO}_{4}\right]$. For a longer time, a small irreversible denaturation of the enzyme was also observed after $6 \mathrm{~h}$ of incubation but $75 \%$ of the enzyme remained active. For Tt $\beta g l y$, the stability in $80 \%$ IL was lower since almost $50 \%$ of the activity was lost after $30 \mathrm{~min}$. For the least thermostable glycosidase, AgaB, $90 \%$ of the enzyme was denatured after only $1 \mathrm{~h}$ of incubation in $80 \%$ $[\mathrm{MMIM}]\left[\mathrm{MeSO}_{4}\right]$.

Again, a correlation was observed between the thermostability of the enzymes and their stability in the presence of a high concentration of IL. High ion concentration can modify the water structure and hence influence the protein hydration environment. In particular, hydrophilic and water-miscible ILs might remove internally bound water from enzymes and lead to loss of enzyme activity. 
Thermostable enzymes are generally characterized by a greater rigidity and a more compact structure, which probably results in a stronger resistance to water abstraction by ILs.

\section{Influence of [MMIM][MeSO 4$]$ concentrations on TmGalA kinetic parameters}

As TmGalA was not irreversibly denatured by a high concentration of IL, this enzyme was chosen to study the effect of increasing IL concentrations on its kinetic parameters. Assuming that no enzyme denaturation occurred during the measurements as demonstrated in Fig. 2, the results presented in Table 1 clearly show that the $k_{\text {cat }}$ dramatically decreases with increasing IL concentration, while $K_{\mathrm{m}}$ remains almost constant at $\mathrm{pH}$ 6.5. Curiously, these kinetic data are compatible with a reversible non-competitive inhibition of the galactosidase by $[\mathrm{MMIM}]\left[\mathrm{MeSO}_{4}\right]$ and an apparent inhibition constant $\mathrm{K}_{\mathrm{i}}=0.35 \pm 0.05 \mathrm{M}$ can be derived from them. Such inhibition could be due to the imidazolium cations of $[\mathrm{MMIM}]\left[\mathrm{MeSO}_{4}\right]$, according to previous observations showing that substituted imidazole behaves as an inhibitor of various glycosidases (Magdolen and Vasella 2005). However, it is more likely that the decrease in $k_{\text {cat }}$ for hydrolytic activity simply reflects the reduced water activity $\left(a_{\mathrm{w}}\right)$ at high IL concentration. This result shows that the reversible inhibition of glycosidases becomes significant at a high percentage of IL in water, which limits the utility of hydrophilic IL with these enzymes.

\section{Conclusion}

Our results indicate a close correlation between the thermostability of the glycosidases and their stability in hydrophilic ILs, suggesting that the more compact structure of the hyperthermostable enzymes prevents ILs from disrupting 
their protein structure. We have also shown that the decrease in glycosidase activity in ILs is caused by both an irreversible denaturing effect and a direct reversible inhibition of the enzyme activity. However, this decrease in hydrolytic efficiency is not correlated to an increase in transglycosylation activity at high donor and acceptor concentration as expected by the decrease in water activity. Taken together, these results demonstrate that it is preferable to use highly thermostable glycosidases for biocatalytic reactions in water-miscible ILs as green solvents.

\section{Acknowledgements}

We are grateful to Prof. Robert M. Kelly for the kind gift of the TmGalA gene. This work was supported by a grant from ANR (ANR-07-CP2D-Glycenli) and S.F. was supported by a France/Algeria grant (C.P.F.S.).

\section{References}

ChiffoleauGiraud V, Spangenberg P, Rabiller C (1997) Beta-galactosidase transferase activity in ice and use of vinyl-beta-D-galactoside as donor. Tetrahedron Asymmetry 8:2017-2023 Comfort DA, Bobrov KS, Ivanen DR, Shabalin KA, Harris JM, Kulminskaya AA, Brumer H, Kelly RM (2007) Biochemical analysis of Thermotoga maritima GH36 $\alpha$-Galactosidase (TmGalA) Confirms the Mechanistic Commonality of Clan GH-D Glycoside Hydrolases. Biochemistry 46:3319-3330

Dion M, Fourage L, Hallet JN, Colas B (1999) Cloning and expression of a beta-glycosidase gene from Thermus thermophilus. Sequence and biochemical characterization of the encoded enzyme. Glycoconj J 16:27-37

Dion M, Nisole A, Spangenberg P, André C, Glottin-Fleury A, Mattes R, Tellier C, Rabiller C (2001) Modulation of the regioselectivity of a Bacillus $\alpha$-galactosidase by directed evolution. Glycoconj J 18:215-223

Feng H-Y, Drone J, Hoffmann L, Tran V, Tellier C, Rabiller C, Dion M (2005) Converting a $\alpha$ Glycosidase into a $\beta$-Transglycosidase by Directed Evolution. J Biol Chem 280:37088-37097 Hanson S, Best M, Bryan MC, Wong CH (2004) Chemoenzymatic synthesis of oligosaccharides and glycoproteins. Trends Biochem Sci 29:656-63 
Kaftzik N, Wasserscheid P, Kragl U (2002) Use of Ionic Liquids to Increase the Yield and Enzyme Stability in the $\beta$-Galactosidase Catalyzed Synthesis of N-Acetyllactosamine. Org Process Res Dev 6:553-557

Kamiya N, Matsushita Y, Hanaki M, Nakashima K, Narita M, Goto M, Takahashi H (2008) Enzymatic in situ saccharification of cellulose in aqueous-ionic liquid media. Biotechnol Lett 30:1037-1040

Kragl U, Eckstein M, Kaftzik N (2002) Enzyme catalysis in ionic liquids. Curr Opin Biotechnol $13: 565-571$

Lang M, Kamrat T, Nidetzky B (2006) Influence of ionic liquid cosolvent on transgalactosylation reactions catalyzed by thermostable beta-glycosylhydrolase CelB from Pyrococcus furiosus.

Biotechnol Bioeng 95:1093-100

Mackensie LF, Qingping W, Warren RAJ, Withers SG (1998) Glycosynthases: Mutant glycosidases for oligosaccharide synthesis. J Am Chem Soc 120:5583-5584

Magdolen P, Vasella A (2005) Monocyclic, substituted imidazoles as glycosidase inhibitors. Helv Chim Acta 88:2454-2469

Mateo C, Palomo JM, Fuentes M, Betancor L, Grazu V, Lopez-Gallego F, Pessela BCC, Hidalgo A, Fernandez-Lorente G, Fernandez-Lafuente R and others (2006). Glyoxyl agarose: A fully inert and hydrophilic support for immobilization and high stabilization of proteins. Enzyme Microb Tech 39:274-280

Miller ES, Jr., Parker KN, Liebl W, Lam D, Callen W, Snead MA, Mathur EJ, Short JM, Kelly RM (2001) $\alpha$-D-Galactosidases from Thermotoga species. (Hyperthermophilic Enzymes, Part A) Methods in Enzymology 330:246-260

Muthana S, Cao H, Chen X (2009) Recent progress in chemical and chemoenzymatic synthesis of carbohydrates. Curr Opin Chem Biol 13:573-81

Sheldon RA, Lau RM, Sorgedrager MJ, van Rantwijk F, Seddon KR (2002) Biocatalysis in ionic liquids. Green Chem 4:147-151

Van Rantwijk F, Sheldon RA (2007) Biocatalysis in Ionic Liquids. Chem Rev 107:2757-2785.

Van Rantwijk F, Woudenberg-van Oosterom M, Sheldon RA (1999) Glycosidase-catalysed synthesis of alkyl glycosides. J Mol Catal B: Enzym 6:511-532 
Table 1. Steady-state kinetic parameters for the hydrolysis of $p \mathrm{NP} \alpha$ gal by TmGalA in $25 \mathrm{mM}$ citrate phosphate buffer, $\mathrm{pH} 6.5$, at $40^{\circ} \mathrm{C}$ in various concentrations of [MMIM] $\left[\mathrm{MeSO}_{4}\right]$.

\begin{tabular}{ccccc}
\hline$[\mathrm{MMIM}]\left[\mathrm{MeSO}_{4}\right]$ & {$[\mathrm{MMIM}]\left[\mathrm{MeSO}_{4}\right]$} & $K_{\mathrm{m}}$ & $k_{\text {cat }}$ & $k_{\text {cat }} / \mathrm{Km}$ \\
$\%$ & $\mathrm{M}$ & $\mathrm{mM}$ & $\mathrm{s}^{-1}$ & $s^{-1} m M^{-1}$ \\
\hline 0 & 0 & $0.11 \pm 0.01$ & $4.8 \pm 0.2$ & 42.7 \\
9 & 0.58 & $0.064 \pm 0.01$ & $2.1 \pm 0.07$ & 33 \\
27 & 1.74 & $0.1 \pm 0.01$ & $0.62 \pm 0.02$ & 6.2 \\
45 & 2.9 & $0.08 \pm 0.01$ & $0.49 \pm 0.02$ & 5.8 \\
\hline
\end{tabular}




\section{Figure Legend}

Fig. 1 Activity of TmGalA, Tt $\beta$ gly and $\mathrm{AgaB}$ at $40^{\circ} \mathrm{C}$ as a function of the concentration of [MMIM] $\left[\mathrm{MeSO}_{4}\right]$ (\% by vol). The initial activity was measured using: $p \mathrm{NP} \beta \mathrm{gal}(1 \mathrm{mM})$ as substrate in $50 \mathrm{mM}$ phosphate buffer, $\mathrm{pH}$ 7, for Tt $\beta \mathrm{gly}(\bullet), p \mathrm{NP} \alpha \mathrm{gal}(1 \mathrm{mM})$ as substrate in 50 $\mathrm{mM}$ phosphate buffer, $\mathrm{pH} 7$, for AgaB ( $\mathbf{\Delta})$ and $p \mathrm{NP} \alpha$ gal $(1 \mathrm{mM})$ in $25 \mathrm{mM}$ citrate/phosphate buffer, pH 6.5, for TmGalA (

Fig. 2 Residual activity of TmGalA, Tt $\beta$ gly and $\mathrm{AgaB}$ at $40^{\circ} \mathrm{C}$ as a function of the incubation time in $[\mathrm{MMIM}]\left[\mathrm{MeSO}_{4}\right]$ ( $80 \%$ by vol). The residual activity was measured after dilution to $5 \%$ [MMIM] $\left[\mathrm{MeSO}_{4}\right.$ ] using: $p \mathrm{NP} \beta \mathrm{gal}(1 \mathrm{mM})$ as substrate in $50 \mathrm{mM}$ phosphate buffer, $\mathrm{pH} 7$, for Tt $\beta$ gly $(\bullet), p N P \alpha g a l(1 \mathrm{mM})$ as substrate in $50 \mathrm{mM}$ phosphate buffer, $\mathrm{pH} 7$, for $\mathrm{AgaB}(\boldsymbol{\Delta})$ and $p \mathrm{NP} \alpha \mathrm{Gal}(1 \mathrm{mM})$ in $25 \mathrm{mM}$ citrate/phosphate buffer, $\mathrm{pH}$ 6.5, for TmGalA(Ш)

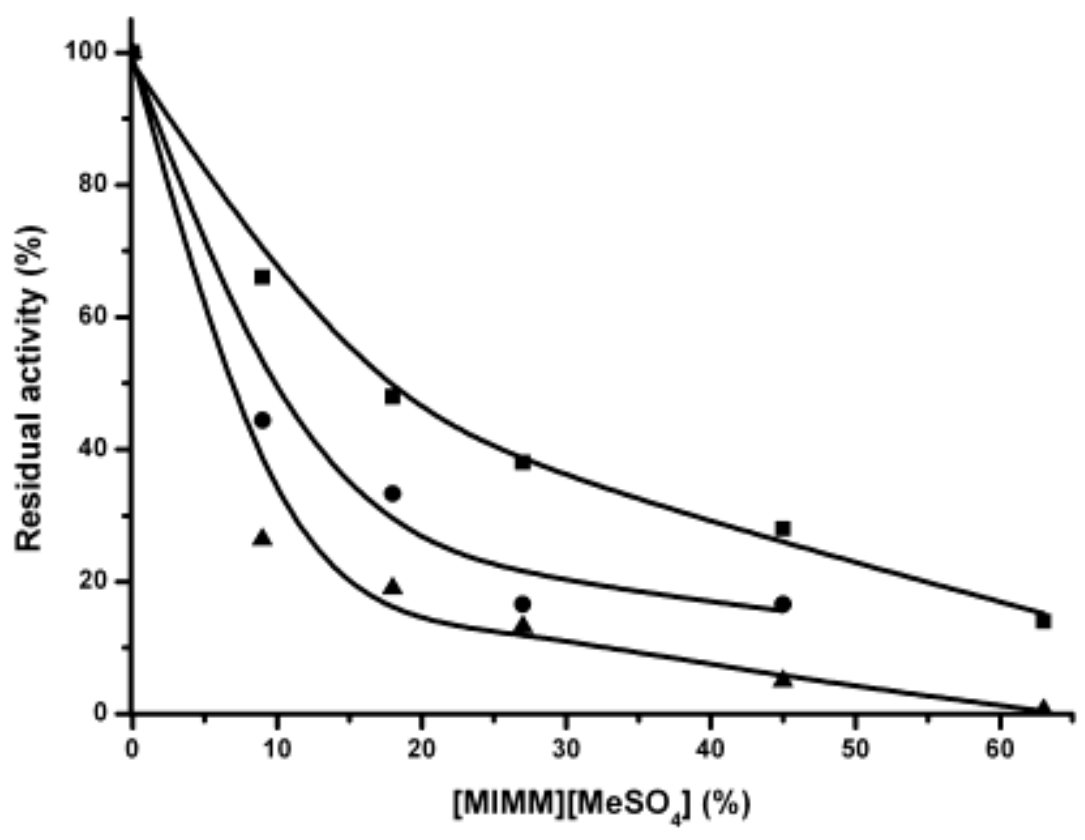




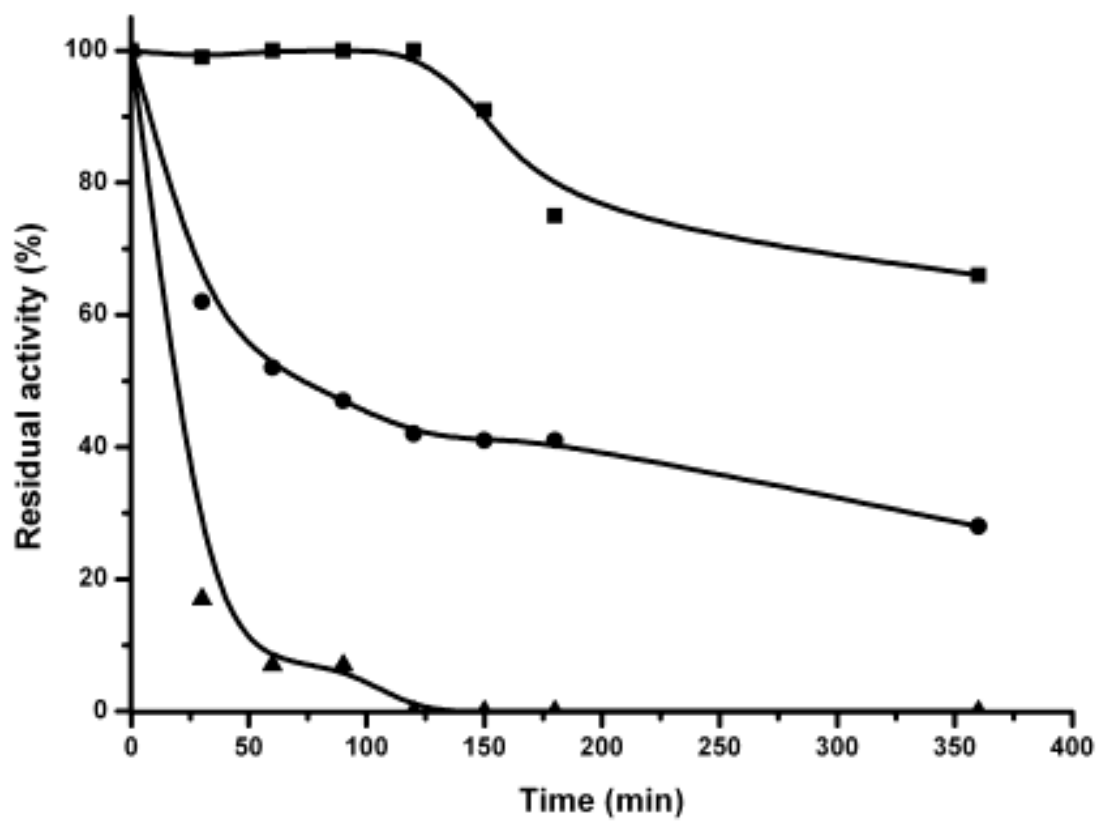

